\title{
Measuremets of sootblower jet strength in kraft recovery boilers - Part II: Results of the third and fourth field trials
}

HONGHI TRAN, AMEYA POPHALI, MARKUS BUSSMANN, AND PASI MIIKKULAINEN

\begin{abstract}
Two additional field trial studies were conducted in different kraft recovery boilers in Sweden using force-measurement probes to determine the force of sootblower jets under various blowing conditions. The results confirm the findings of previous trials that, at a given distance, the force exerted on a target by a fully expanded sootblower jet increases nearly linearly with an increase in lance pressure. At a given lance pressure, the jet force decreases drastically as the distance between the sootblower nozzle and the target increases. At a distance farther than $1 \mathrm{~m}$ from the nozzle, the jet retains less than $10 \%$ of its original strength. The studies also show clearly that the size and shape of the target have a significant effect on the force exerted on it by the jet. A flat surface receives a greater force from the jet than a target with an inclined surface.

Application: Understanding how a sootblower jet behaves and factors that affect the jet strength assist recovery boiler operators and engineers in developing effective sootblowing strategies to maximize deposit removal and boiler availability.
\end{abstract}

S otblowers are used to remove fireside deposits from heat transfer surfaces in kraft recovery boilers. As such, they are of vital importance for the thermal performance and production capacity of the boilers. The ability of a sootblower jet to remove a deposit is directly related to the jet strength (force) exerted on the deposit during blowing. Many studies have been performed over the past two decades to examine jet characteristics and interaction with tubes and deposits; most studies were performed under well controlled laboratory conditions [1-3].

In late 2007, a collaborative project was initiated by Andritz to systematically measure sootblower jet strength in-situ [4]. The study involved designing and constructing two forcemeasurement systems to use in determining the jet force directly in operating recovery boilers. Prior to this project, no similar study has been reported in the literature, owing understandably to the harsh environment in the boilers.

The objectives of this study were to obtain field data on jet strength, compare them with laboratory data, and use them to validate the SJT (Sootblower Jet Turbulence) model that has been developed through the years at the University of Toronto for predicting the behavior of sootblower jets $[5,6]$.

A total of four field trials were conducted. The first three trials (Trials 1, 2 and 3) were carried out in a recovery boiler at the SCA packaging mill in Obbola, Sweden. The fourth trial (Trial 4) was in a recovery boiler at the Södra Cell mill in Värö, Sweden. The force-measurement probe design, test procedures, and results obtained from the first two trials (Part I of the project) have been discussed in detail in a paper published recently in TAPPIJournal by Saviharju et al. [4].

The main conclusions obtained in Part I were that, at a given sootblowing lance pressure, the jet force diminished markedly with an increase in distance between the sootblower nozzle and the target. At $1 \mathrm{~m}$ from the nozzle, the jet exerted only $10 \%$ of its maximum possible force on the same target. At a longer distance, the jet struck the target not only with a weaker force, but also for a shorter period of time.

These trials also showed that the jet strength fluctuated widely, particularly when the jet was close to the target. The fluctuation was due mainly to the vibration of the target as it was struck by the jet and to a lesser extent, the change in jet strength caused by platen swinging and tremor of the system that held the target. The surrounding flue gas temperature was found to have an insignificant effect on jet strength.

This paper concerns Part II of the collaborative project involving Trial 3, which used different target sizes and shapes, and Trial 4, which used a different recovery boiler with a different force-measurement system design.

\section{TRIAL 3: OBBOLA MILL}

Trial 3 was performed in November 2008 in the same recovery boiler as Trials 1 and 2 at the Obbola kraft mill. This is a small recovery boiler, with a distance between the front wall and the nearest sootblower in the superheater region of only $3.5 \mathrm{~m}$. A $4.4 \mathrm{~m}$ long force-measurement probe inserted through the front wall of the boiler (Fig. 1) made it possible to deter- 


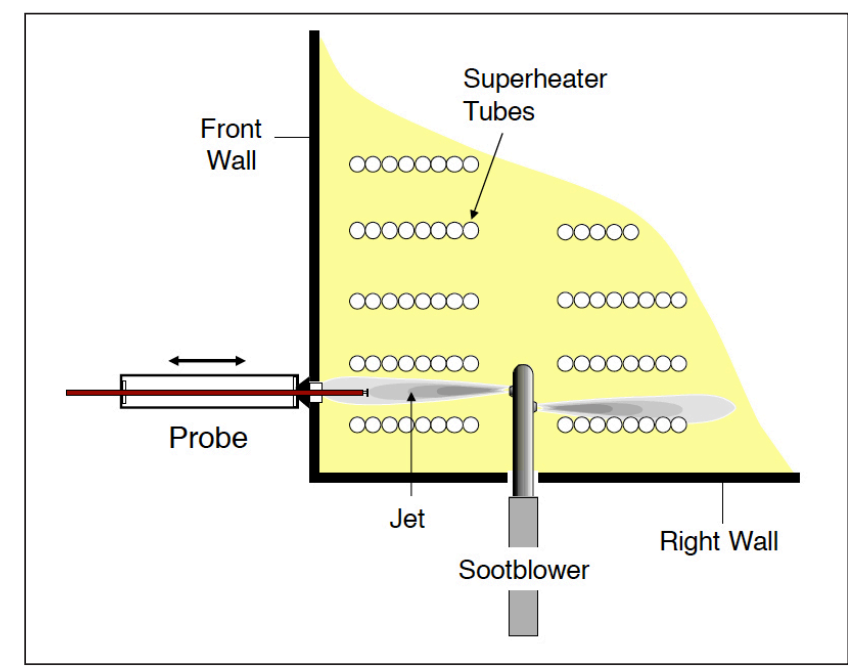

1. Force measurement probe and sootblower locations in the boiler at Obbola.

mine the sootblower jet force at any distance up to $2.5 \mathrm{~m}$ between the sootblower nozzle and the target plate of the probe.

\section{Probe design and trial procedures}

The probe system and trial procedures used in Trial 3 were essentially the same as in the previous trials [4], except that the target plates were of different sizes and shapes. As shown in Fig. 2, instead of the 48-mm-diameter round target plate used in Trials 1 and 2, four square targets were used in Trial 3: one flat square target $\left(180^{\circ}\right)$ and three arrow-shape targets with different wedge angles of $90^{\circ}, 60^{\circ}$, and $30^{\circ}$. Although these targets had the same projected area, $48 \mathrm{~mm} \times 48 \mathrm{~mm}$, they were exposed to the sootblower jet at different angles: $90^{\circ}, 130^{\circ}, 150^{\circ}$, and $165^{\circ}$, respectively. The objective was to determine what impact the target shape and the jet blowing angle have on the force exerted by the jet on the target.

Only the sootblower that was closest to the probe was tested. As the jet struck the target at the front end of the probe inside the boiler, it exerted a force on the target, pushing the rod against the force transducer mounted at the cold end of the probe outside the boiler. This caused the transducer to produce a signal proportional to the jet strength. The signal was continuously monitored at high sampling rates using a data acquisition system during each test.

The jet force was measured at three distances: $300 \mathrm{~mm}$, $750 \mathrm{~mm}$, and $1200 \mathrm{~mm}$, and at a lance pressure varying between 10 and 15 bars. One target shape was tested at a time. The target was fixed at one position, while the sootblower was operated in the usual manner, with the lance rotating and moving forward and backward in the boiler so that its opposing jets hit the target one after the other.

The recovery boiler operating condition in Trial 3 was different than the previous two trials. In Trial 1, the boiler had not yet been in commission. The tests were performed while the boiler was on oil with the flue gas temperature at the test site varying between $100^{\circ} \mathrm{C}$ and $300^{\circ} \mathrm{C}$. The steam for the
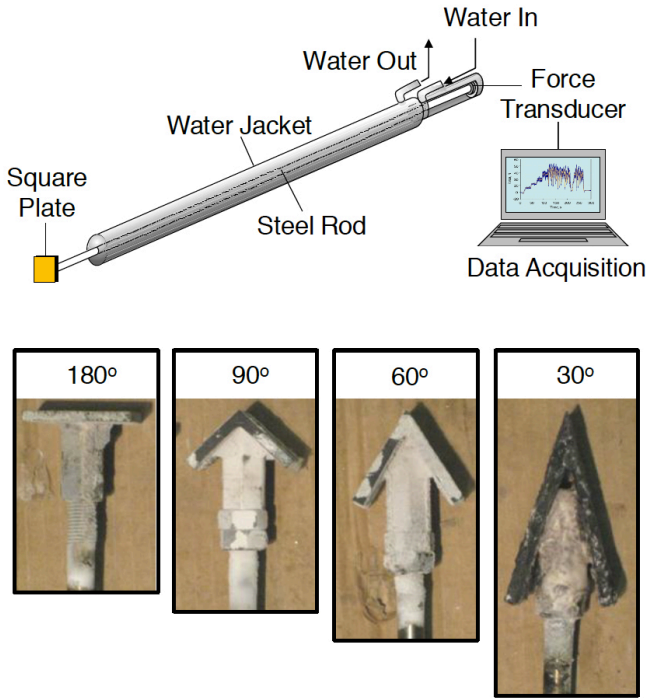

2. Probe schematic and photos of different target shapes used in Trial 3.

sootblower was delivered from a hog fuel boiler nearby.

Trial 2 was performed in November 2007, two months after Trial 1 . The recovery boiler was in operation but at a low liquor firing load with the flue gas temperature near the test site only $500^{\circ} \mathrm{C}-540^{\circ} \mathrm{C}$.

Trial 3 was conducted a year after Trial 2 , with the boiler at a higher firing rate. The steam for the sootblower in both Trials 2 and 3 was taken from the recovery boiler itself.

There were two main sources of errors in the jet force measurements. One was the misalignment between the jet and the probe target. The other source was the friction between the steel rod and the probe assembly. The probe must be aligned exactly along the jet axis in order to register the maximum available jet force. In Trial 1, the alignment was done when the boiler was "cold" (i.e., before it was on oil), while the probe target is brought into direct contact with the sootblower nozzle and then withdrawn to a set distance along the jet axis [4].

Unfortunately, this method of alignment was not possible in other trials because the recovery boiler was in operation and hot. The alignment was instead performed with the aid of a high-temperature infrared camera. The limited view of the camera, however, made the aligning procedure difficult, particularly when the probe target was placed near the sootblower nozzle and its vibration became excessive. Repeated measurements were needed to minimize errors caused by misalignment.

The effect of friction between the rod and the probe tube was determined by turning the adjusting screw on the probe assembly back and forth. When the probe was clean, the error caused by friction was found to be within $\pm 10 \mathrm{~N}$. When the probe was covered with a layer of deposit, the friction became large, substantially reducing the force transducer signal. When this happened, the probe was taken out of the boiler, cleaned, and reused. 


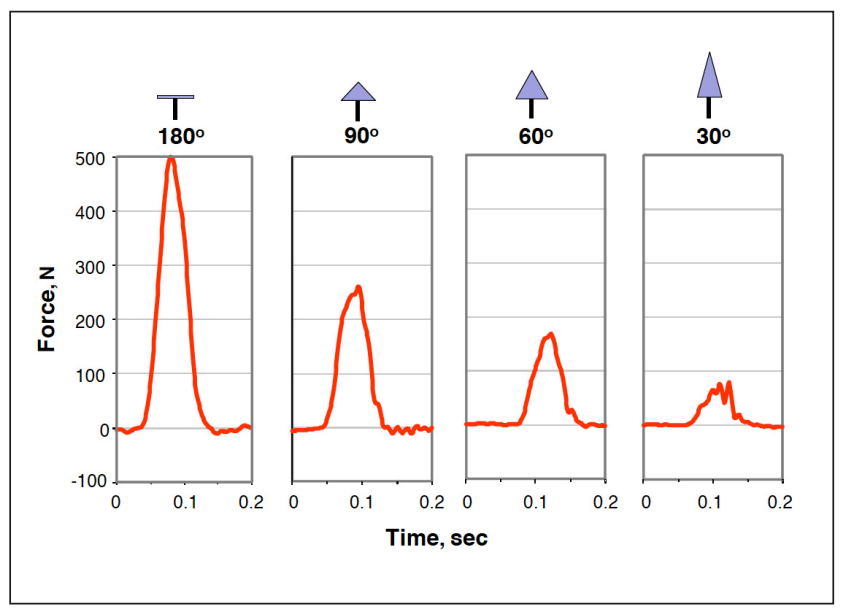

3. Jet impacts at $300 \mathrm{~mm}$, measured with different target heads.

\section{Effect of target shape}

Figure 3 shows the effect of target shape on jet force measured at $300 \mathrm{~mm}$ from the nozzle. The force decreased markedly as the target was changed from a flat plate $\left(180^{\circ}\right)$ to various arrow shapes, despite the fact that the cross sections (projected areas) for all of these shapes were the same. The sharper the arrow wedge angle, the smaller the measured force. This is not surprising since a streamlined, elongated object tends to be aerodynamically less resistant to flow than a flat surface [7].

Figure 4 plots the jet force against target wedge angle. The relationship appears to be linear and fits well with the following equation:

$$
\mathrm{F}_{\theta}=\frac{\theta}{180} \times \mathrm{F}_{\max }
$$

where $\mathrm{F}_{\theta}$ and $\mathrm{F}_{\max }$ are the jet force exerted on the target with a wedge angle $\theta$ and the maximum jet force exerted on a flat $\left(180^{\circ}\right)$ plate target of the same projected area, respectively; $\theta$ is the target head angle in degrees, as shown in Figs. 2 and 3.

The result suggests that a flat target experiences the greatest force from a sootblower jet normal to the target surface compared to other wedge shape targets of the same crosssectional area. Thus, a flat plate is the best target design for use in measuring the jet strength, as it provides the strongest and smoothest possible signal from a sootblower jet.

Figure 5 shows the average jet force as a function of distance from the nozzle at the sootblower lance pressure of about 10 bars (9-11 bars). Infrared inspection cameras were not available in Trial 3; therefore, alignment of the probe target with the sootblower jet axis was done based on records/ experience obtained from the previous trials. Despite the alignment difficulty, no significant difference in results was observed. Trials 1 and 2 show practically identical results (circle markers) at a given distance. Trial 3 shows a slightly greater force (yellow squares). The higher force value obtained for Trial 3 was likely due to the larger projected area of the square

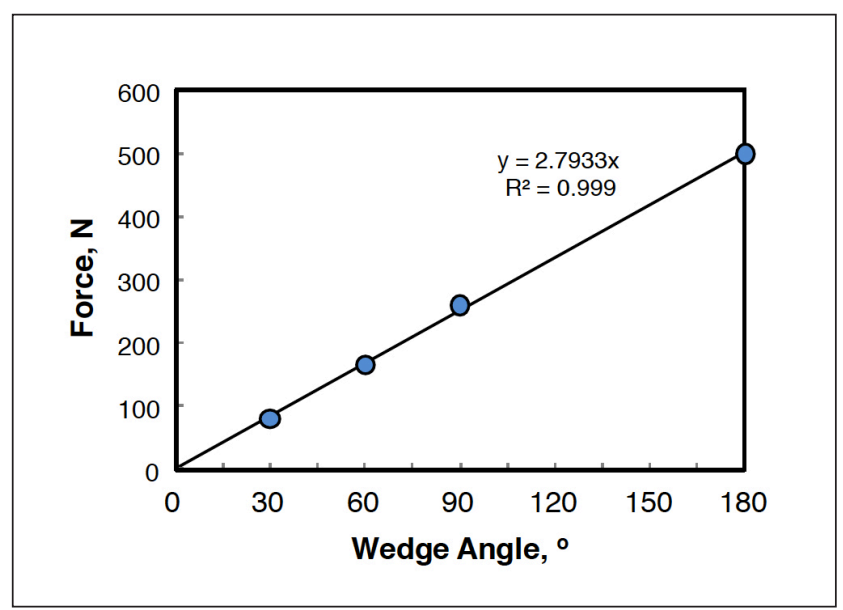

4. Effect of wedge angle on jet impact force measured at $300 \mathrm{~mm}$.

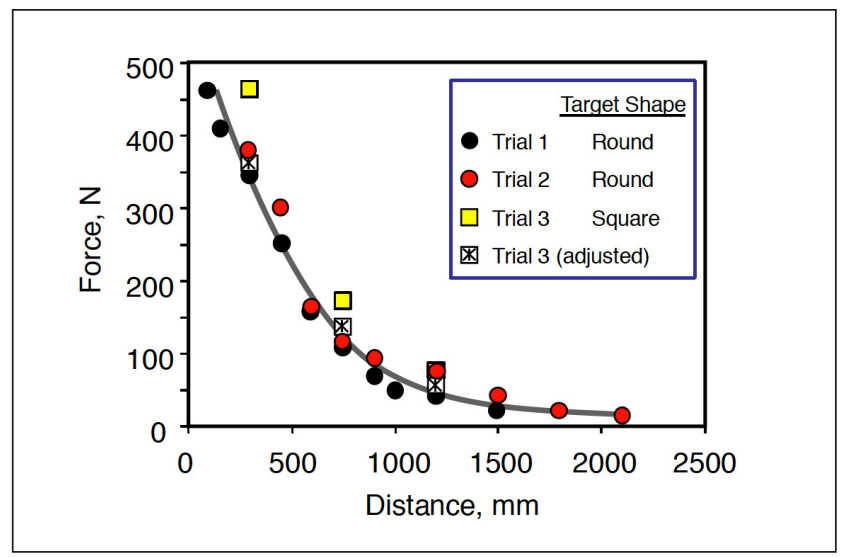

5. Average measured force vs. distance for Trials 1, 2 and 3 at Obbola. Lance pressure: 9 to 11 bars (150 psi).

target ( $48 \mathrm{~mm} \times 48 \mathrm{~mm}$ ) used. The projected area was $28 \%$ larger than that of the round target ( $48 \mathrm{~mm}$ in diameter) used in the previous two trials, causing it to register a proportionally greater force. After adjusting for this larger surface area, the Trial 3 data (white squares) is in much better agreement with the data obtained from the other trials.

\section{TRIAL 4: VÄRÖ MILL}

\section{Probe design and test procedure}

Trial 4 was performed at the Södra Cell Värö mill in February 2009. The recovery boiler is a larger unit than that at the Obbola mill where the first three trials took place. The front wall of this boiler was farther from the nearest sootblower in the superheater region, preventing the use of the force-measurement system used in the earlier trials. It was difficult to align the sootblower nozzle with the probe to allow the jet to reach the probe target. As a result, the force-measurement system was redesigned for this trial.

As shown in Fig. 6a, in addition to the water jacket, the probe was cooled by air to protect the sensor element (force transducer) installed inside the probe at the hot end. The probe was introduced into the boiler through a manhole un- 


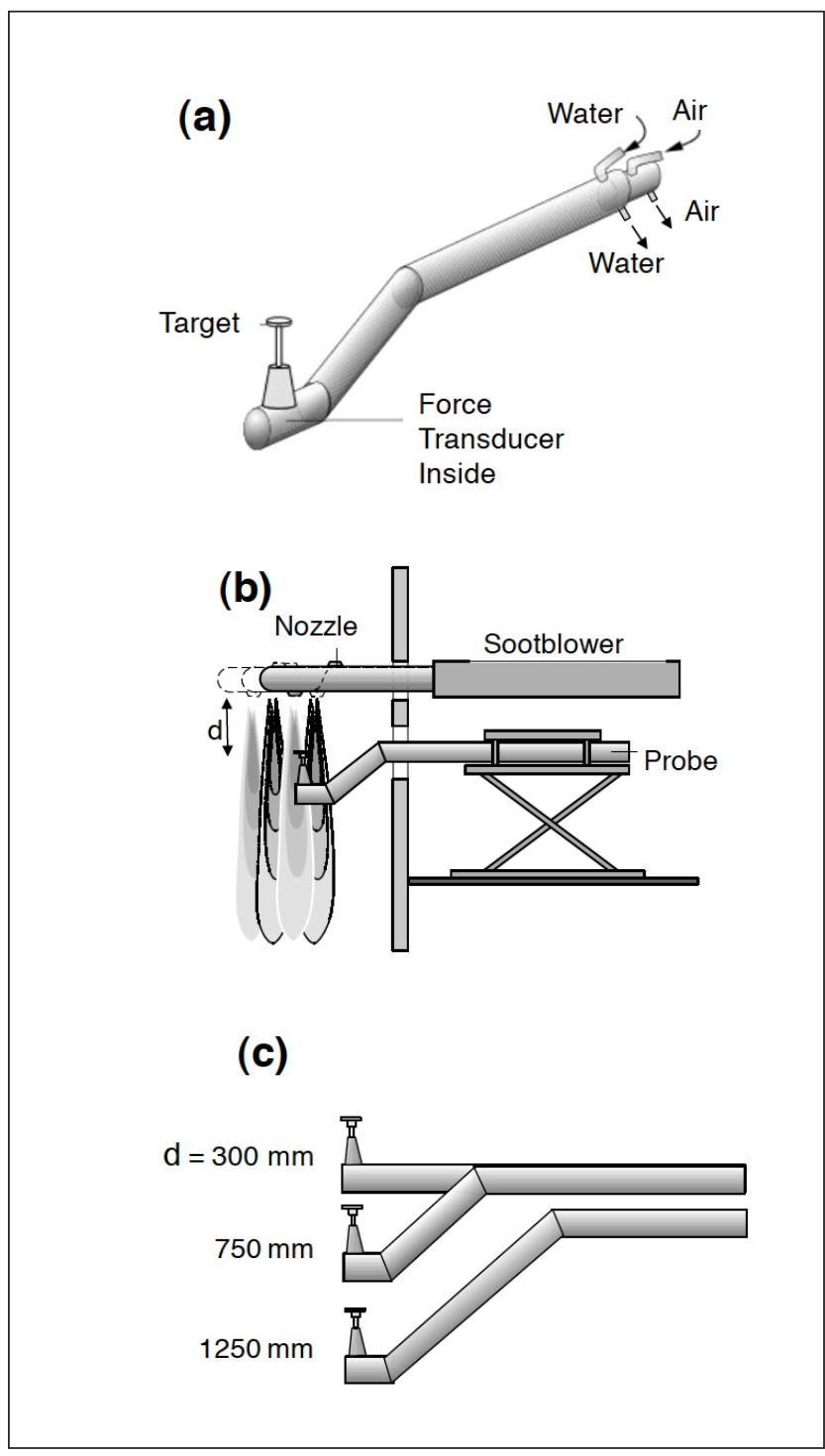

6. Force measurement system used for Trial 4 at the Värö mill.

derneath a sootblower on a side wall of the boiler (Fig. 6b). Three different probe geometries were used to change the distance between the sootblower nozzle and the probe target, as shown in Fig. 6c. These probes allowed force measurements to be made at $300 \mathrm{~mm}, 750 \mathrm{~mm}$, and $1250 \mathrm{~mm}$ from the sootblower nozzle.

A "blind" procedure was used to align the probe target with the sootblower nozzle. During alignment, the probe was inserted horizontally into the boiler in $30 \mathrm{~mm}$ increments. The impact of the jet on the probe was recorded at each increment. When the target plate was located directly opposite the nozzle position at the instant of impingement, only one high amplitude impact would register (Fig. 7a). When the target plate was located between two sequential positions of the nozzle, two impacts of comparable strength would register (Fig. 7b). When the probe target position yielded a single, high amplitude signal, this was considered to be the best alignment between sootblower nozzle and probe. This posi-

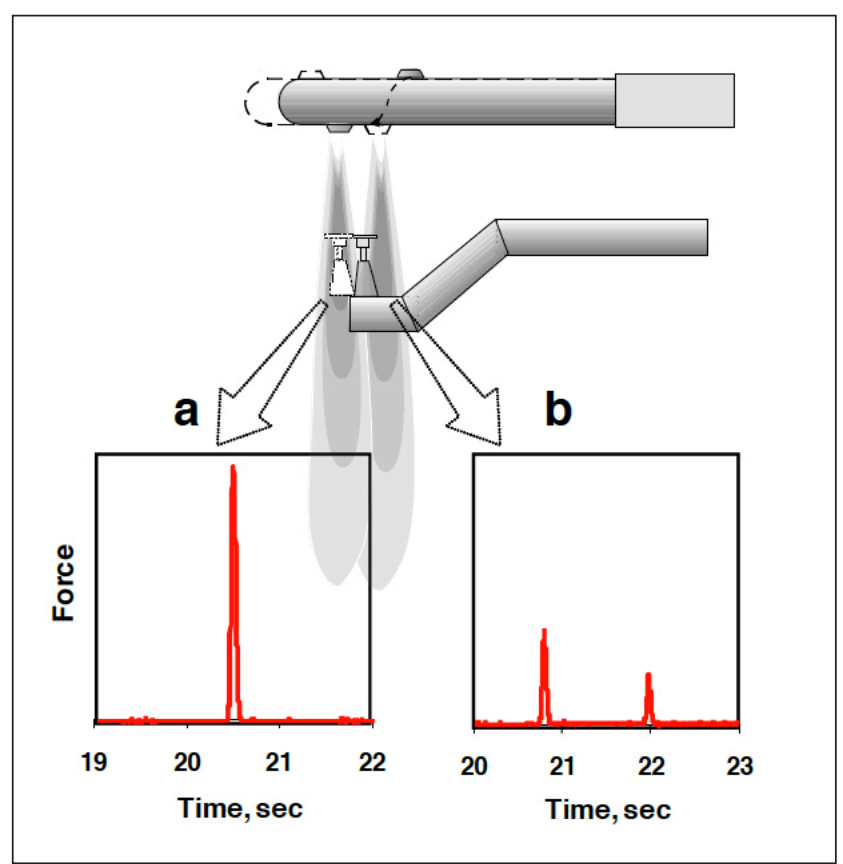

7. Probe alignment in Trial 4. a) Good alignment resulted in a single high intensity peak; b) poor alignment resulted in two smaller peaks caused by subsequent impacts.

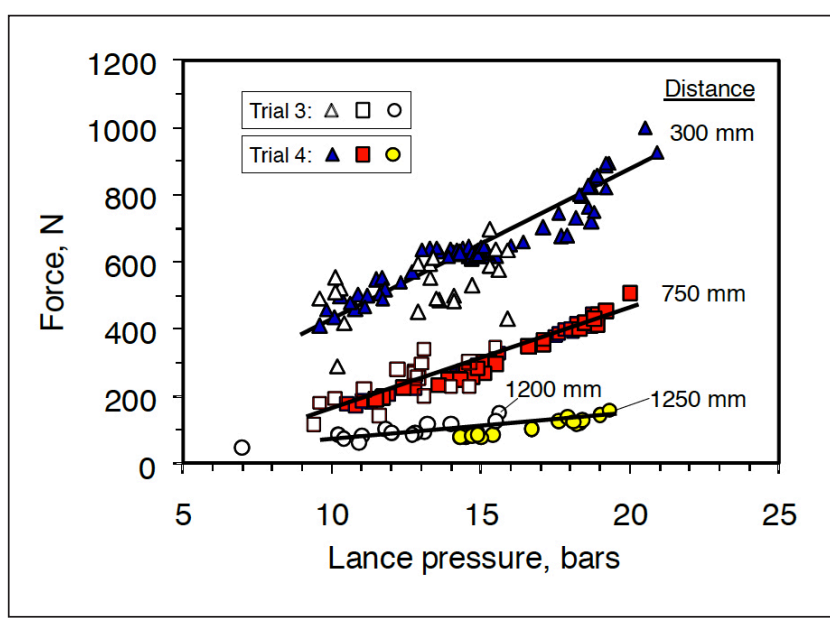

8. Jet force as a function of lance pressure and distance from the nozzle (the blank markers are data from Trial 3; solid markers are data from Trial 4).

tion was subsequently used to measure the jet strength.

\section{RESULTS FROM TRIALS 3 AND 4}

The measurements obtained in Trial 4 with the new probe design had a better reproducibility than those obtained from the first three trials. Figure $\mathbf{8}$ shows measured jet force as a function of lance pressure for three distances from the nozzle: $300 \mathrm{~mm}, 750 \mathrm{~mm}$, and $1250 \mathrm{~mm}$. The blank markers represent Trial 3 data while the solid markers represent Trial 4 data. No measurements were taken at $1250 \mathrm{~mm}$ in Trial 3, and the data at $1200 \mathrm{~mm}$ is plotted. 
Both Trials 3 and 4 show similar results, although the data for Trial 4 appears to be less scattered. This confirms that the force produced by a sootblower jet increases almost linearly with an increase in lance pressure.

\section{CONCLUSIONS}

The results obtained confirm the findings of the previous trials, demonstrating that at a given distance, the force produced by sootblower jet increases almost linearly with an increase in lance pressure. At a given lance pressure, the jet force decreases rapidly as the distance increases, retaining less than $10 \%$ of its original strength at a distance of $1 \mathrm{~m}$ from the nozzle.

The results also reveal that the exerted force is directly proportional to the projected area of the target. It is highest when the target is flat and increases linearly with an increase in wedge angle of the target.

These field data on sootblower jet strength are very valuable, allowing us to validate the sootblower jet turbulence model that has been developed in our laboratory, and to use the validated model to predict sootblower jet strength in recovery boilers. TJ

\section{DEDICATION}

This paper is dedicated to Kari Saviharju of Andritz who initiated the project and helped bring it to fruition. Mr. Saviharju died of cancer in December 2008.

\section{ACKNOWLEGEMENTS}

The authors wish to acknowledge the Obbola and Värö mills for providing test sites and help during the trials; YTI Research Centre, Finland for its assistance with probe design and con- struction; Lars-Gunnar Magnusson of Andritz for his leading role in the collection of field data and Dr. Andrei Kaliazine for his assistance with data analysis. This work was conducted as part of the research program on "Increasing Energy and Chemical Recovery Efficiency in the Kraft Process," jointly supported by the Natural Sciences and Engineering Research Council of Canada (NSERC) and a consortium of the following companies: Andritz, Babcock \& Wilcox, Boise Paper, Carter Holt Harvey, Celulose Nipo-Brasileira, Clyde-Bergemann, DMI Peace River Pulp, Fibria, International Paper, Irving Pulp \& Paper, Metso Power, MeadWestvaco, StoraEnso Research, and Tembec.

\section{LITERATURE CITED}

1. Kaliazine, A., Cormack, D.E., Ebrahimi-Sabet, A., et al., J. Pulp Pap. Sci. 25(12): 418(1999).

2. Mao, X., Tran, H.N., and Cormack, D.E., TAPPI J. 84(6): 68(2001).

3. Pophali, A., Eslamian, M., Bussmann, M., et al., TAPPI J. 8(9): 4(2009).

4. Saviharju, K., Kaliazine, A., Tran, H.N., et al., TAPPI J. 10(2): 27(2011).

5. Tandra, D., Kaliazine, A., Cormack, D.E., et al., Pulp Pap. Can. 108(5): 43(2007).

6. Emami, B., Bussmann, M., Tran, H.N., et al., Int. Chem. Recovery Conf., TAPPI PRESS, Atlanta, GA, USA, 2010, Conf. CD.

7. Hoerner, S.F., "Fluid Dynamic Drag: Practical Information on Aerodynamic Drag and Hydrodynamic Resistance," Hoerner Fluid Dynamics, S.F. Hoerner, Midland Park, NJ, USA, 1965.

\section{ABOUT THE AUTHORS}

This research is a continuation of previous studies we conducted to validate our laboratory and computer simulation results. The research focuses on the effects of various target shapes on sootblower jet performances.

It is difficult to design and construct force measurement equipment able to withstand the harsh environment of operating recovery boilers and reliably measure the sootblower jet force in-situ. Jet strength is surprisingly affected by superheater platen swinging.

Our research focus will now turn to computer simulation of sootblower jet performance so that mills, in developing efficient sootblowing strategies, maximize deposit removal and boiler availabilities.

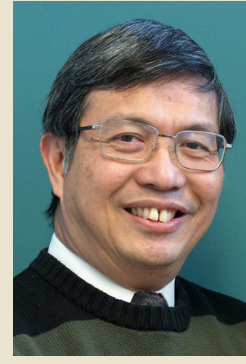

Tran

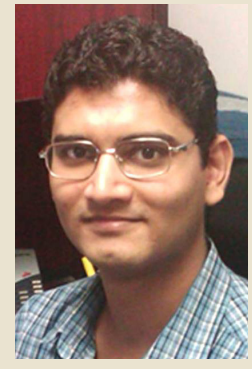

Pophali

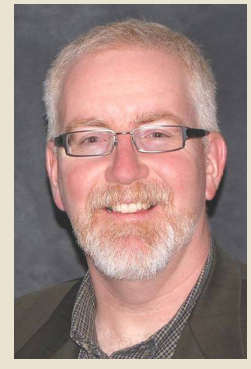

Bussmann

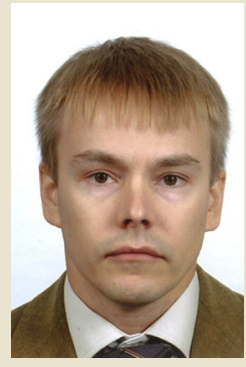

Miikkulainen
Tran is the Frank Dottori Professor of Pulp \& Paper Engineering and Pophali is a Ph.D. candidate in the Department of Chemical Engineering \& Applied Chemistry at the University of Toronto, Toronto, ON, Canada. Bussmann is a professor in the Department of Mechanical and Industrial Engineering at the University of Toronto. Miikkulainen is a manager with Andritz Inc. in Kotka, Finland. Email Tran at honghi.tran@utoronto.ca. 